\title{
Lewis Feuer, A Centenary Appreciation
}

\author{
John Rodden
}

Published online: 25 October 2012

(C) Springer Science+Business Media New York 2012

\section{Of Sociology and the Intellectual Life}

This year marks the centenary of Lewis S. Feuer's birthand I regret to say that it will probably pass unnoticed outside this journal's pages. If so, that is both regrettable and unjust. For more than a decade, from the mid-1950s to the late 1960s, Feuer was regarded as the leading left-wing sociological theorist in North America. His work combines innovative theoretical perspectives with powerful, highly original methodological approaches, resulting in major studies in the sociology of philosophy and science, the history of ideas, the sociology of ideology, the sociology of generations, and the sociology of imperialism, among other fields of scholarship. Those are only a selection of his disciplinary interests as a sociologist and intellectual. In fact, Feuer's oeuvre is so diverse and encompassing that it is likely to appear mind-boggling, if not somehow suspect, to many present-day disciplinary specialists.

Feuer's work is distinguished by a commanding knowledge of social history and the history of ideas. Of the influences on Feuer's work as a historian of ideas, Arthur O. Lovejoy above all inspired him. Feuer's contribution to that subfield is most evident in three landmark studies: Spinoza and the Rise of Liberalism (1958); The Scientific Intellectual (1963); and Einstein and the Generations of Science (1982), along with dozens of scholarly articles. Best characterized as a sociology of ideas grounded in general history, Feuer's sociology of knowledge represents an epistemology of diverse theoretical concepts in the sciences and social sciences (e.g., Einstein's theory of relativity and Freud's psychoanalysis).

J. Rodden $(\bowtie)$

118 Beautybush Trail,

Georgetown, TX 78628, USA

e-mail: jgrodden@yahoo.com
Born in December 1912 in New York City, Lewis S. Feuer was educated at City College of New York, gaining his B.S. degree in 1931 at the age of eighteen. He entered Harvard University and received his M.A. in 1932 and $\mathrm{Ph} . \mathrm{D}$. in philosophy in 1935 at the age of twenty-two. His dissertation, completed under the direction of Alfred North Whitehead, was entitled The Philosophical Analysis of Space and Time. Feuer remained philosophically inclined throughout his life, but his primary identity became that of a sociologist. Proceeding against the grain of mainstream sociology, however, his thinking was always different, even iconoclastic. In an intellectual career that spanned almost 70 years, Feuer produced a rich and distinctive sociology that deserves to be reconsidered and extended in new directions.

\section{Mind as Passion}

I first met Lewis Feuer at Virginia, where I audited his classes, initially as a Ph.D. student and subsequently as a junior professor. I was deeply impressed by his fascinating lecture courses on the history of Marxism and on the sociology of Marxism and neo-Marxism. Feuer possessed not only a sophisticated theoretical intelligence, but also an encyclopedic mind for historical and biographical detail, both of which were always on display - exhibited effortlessly and without ostentation - in his classes and public lectures. This was especially true when it came to the Marxist tradition and the intellectual history of the European Left, as I repeatedly discovered in numerous conversations with him. I also had the good fortune to engage him as a colleague in formal scholarly settings on two memorable occasions, first in 1983 during the Karl Marx Centennial Conference and then again in 1984 during the George Orwell Symposium, both of which were sponsored by the Department of Government at Virginia. 
My most memorable and cherished encounters with him, however, occurred in our exchanges in Virginia's Alderman Library, where he often seemed to me to have camped outor perhaps held a one-man sit-in. It was not at all unusual, soon after he entered at 8 a.m., to see him hunkered down at a remote table surrounded by his voluminous stack of leftist papers and books ("anti-capitalist encirclement," I once joked) already piled high. It would continue to ascend as he worked late into the night before his departure at closing time. Feuer never learned to drive a car. Mornings and evenings, I would see him lugging his scholarly treasure trove to and from the nearby library stop.

Reportedly open to befriending students and colleagues in his earlier years, Feuer had become quite guarded, indeed a virtual recluse by the time I made his acquaintance in 1982. So I regarded it as a great privilege to speak with him so frequently and extensively. Because of his reclusiveness and the perception that he was utterly and hopelessly politically incorrect, Feuer was shunned by most people. I suspect that he came to prefer it that way-it enabled him to be selective in his relationships and to have time to get his work done. He had little contact with either colleagues or students outside departmental meetings and his formal class obligations. A tell-tale sign of what he called his postBerkeley "leper status" as a sociologist, he said, was that he belonged to the Department of Government - a field to which he had no close connection throughout his earlier career, except in the broadest sense as a student of political philosophy. But no other department would take himcertainly not sociology, nor Virginia's philosophy department with its allegiance to analytic philosophy, nor even history.

On seeing him squirreled away in some library nook, I would offer a slight wave of acknowledgment as a respectful greeting. Often Feuer's reply was to keep his head down and gaze in the opposite direction, an obvious signal to me that he wished to remain undisturbed. I would pass quietly by. Yet my diffident gesture was occasionally rewarded with a tentative, receptive nod, accompanied by a widening, ironic grin and the words, "Well, well... Mr. Rodden." Or if Feuer was in a playful, mischievous mood: "Well, well... Mr. Orwell."

He would then take a break from his Stakhanovite labors, which would be spread out across four or five large library tables, all pushed together to form a single, impressively mammoth, executive conference table. Although he was personally reticent (to the point of secretiveness, complained some senior colleagues), he was quite forthcoming when I asked him about fellow scholars and intellectuals of his acquaintance. I loved to hear him pontificate about them - and his reminiscences not seldom even led to the offer of an introduction. He would then flip through his address book to vouchsafe me the address of a friend or colleague.
For instance, when I mentioned that I was going to the Orwell Archive in London to complete research on a study of Orwell's reputation among intellectuals, and that I would be interviewing various acquaintances of Orwell, Feuer casually asked about some of them and then inquired, as if it were the most natural thing in the world: "Might you be interested in stopping to see Arthur Koestler?" I nearly jumped out of my seat with eagerness: "Would I?!!!" At other times, Feuer would share his personal impressions of distinguished academic colleagues throughout the country, not all of whom he admired. When I mentioned that I had been impressed by the work of Ernest Becker, a former Berkeley colleague who received a Pulitzer Prize posthumously for The Denial of Death (1974), Feuer quickly shook his head: "Soft-headed and fashionable." The dismissal was definitive. A defender of the student protests at Berkeley, Becker had been on the opposing side of Feuer during the years of the Free Speech Movement in the mid1960s, and perhaps their political differences influenced Feuer's judgment. When Becker resigned his professorship after castigating the Berkeley administration for its resistance to the student radicals' demands, a principled gesture to which the Berkeley student body responded -in unprecedented and astounding fashion - by canvassing funds to pay his salary privately and thereby continue teaching his full-time schedule at Berkeley, it cannot have escaped Feuer's notice that Becker's campus-wide popularity contrasted with Feuer's persona non grata status.

On the other hand, Feuer regarded Philip Rieff as an "outstanding and courageous thinker." I was not surprised, since Rieff advanced a stern critique of the contemporary university in Fellow Teachers (1975) that resonated with Feuer's own. Moreover, Rieff was also a brilliant humanist and an outsider in the field - a maverick, interdisciplinary thinker, not at all a specialist in a sociological niche. Most importantly, Rieff was a sociologist and generational peer who believed in the value of enriching sociology via psychology. Freud: The Mind of the Moralist (1961) and The Triumph of the Therapeutic (1966) remain landmark studies written with penetrating, nuanced insight and literary distinction.

Because I was so interested in contemporary intellectual life, my conversations with Feuer frequently concerned American and British intellectuals, a number of whom he knew personally. Discussing Sidney Hook's autobiography, Out of Step (1986), Feuer told me how Hook had recently phoned him and insisted that he was no "neoconservative" but always and ever still a "socialist." Feuer joked to me that he told Hook in reply: "Sidney, given your hawkish politics, you are the only man on the planet who could possibly maintain such a view!" Feuer himself was writing for Commentary and closely acquainted with many neoconservatives at the time. 
Feuer would also share his impressions about some of his students. He had known Mario Savio, leader of the Free Speech Movement, before the protests began. Savio had attended Feuer's courses, and Feuer expressed an ongoing affection for him despite their political differences. He was less enamored of Susan Sontag, who had also been a student (or auditor) in some of his classes. Certainly his friendship with Rieff, her ex-husband, would not have raised Feuer's opinion of her.

After leaving Virginia to teach at the University of Texas in 1989, I briefly lost contact with Feuer. In the mid-1990s, we re-established our connection, which led in late 1996 to my last personal encounter with him. Along with Thomas Cushman, I visited Feuer at his home in Newton, Massachusetts, to which he had recently retired as professor emeritus from the University of Virginia in Charlottesville. I tape-recorded more than a dozen hours of interviews and conversations during that visit. It was a great pleasure to give these heirlooms to his daughter, Robin Feuer Miller-a Slavic professor (like her mother, Katherine) at Brandeis University-15 years later during a lunch where we renewed our acquaintance. Somehow it felt that a full circle had been traversed and closed. Robin had grown up in Charlottesville and was occasionally home on visits when I was a student and faculty member there.

\section{Fate of a Polymath and Ideological Skeptic}

Polymaths such as Feuer rarely contribute significantly to contemporary social science, a fact that has operated to the disadvantage of Feuer's reputation and legacy. My own conviction, however, is that his finest writings possess scope and substance, breathtaking vision, penetrating insight, conceptual power, and systematic presentation. Perhaps they may ultimately win the attention and support of a new generation of sociological thinkers truly committed to exploring how "interdisciplinarity" can enliven and enrich the sociological imagination. If so, in the long run Feuer might occupy a place in the broader tradition of sociology.

Yet my conditional predicates should be underscored. Feuer's future reputation will depend on whether discerning scholars appreciate how his books overflow with stimulating perceptions and arresting formulations able to irrigate diverse fields of study. Feuer's work can instruct us how to understand numerous problems that confront culture and society today. Deeply convinced of the value of sociological generalizations, a position in contemporary academe under relentless attack from particularizing postmodernisms, Feuer characteristically drew on a cornucopia of historical detail in order to range from concept to example and theory to narrative, lending his most distinguished work a magnificent sweep that persuasively establishes what sociologists call the "micro-macro link" between the levels of the individuum and the societal.

Feuer's enduring commitment to sociological generalization exemplifies how a thinker can adamantly devote a career to "big-picture" projects that resist intellectual fads and fashions, whether of ideology (his outspoken criticism of and consequent ostracism by Sixties radicals) or within academe (mainstream social science) - and also shows the high price of neglect that such a choice may cost him. For those readers acquainted with his oeuvre, however, the edifying pleasure of following a gifted thinker who boldly relates unexpected phenomena and theoretical ideas to a range of substantive topics that first appear utterly unrelated is wondrous. Such work is extremely rare, for scholarship that does not succumb to the institutional rewards for overspecialization has usually suffered from a vice at the polar opposite: grand theory. Feuer deftly avoids both extremes. For example, in one passage of gratuitous insight in Einstein and the Generations of Science, Feuer explains how the same processes that gave rise to Einstein's theory of relativity bear on the origin of the student movement at Berkeley in the 1960s.

Feuer's life and work attest to how ideologies - political or scholarly - blind us to the truth and how intellectuals throughout history - especially in the twentieth centurysurrendered their intellectual and moral integrity to the corruptions of ideology. Feuer saw John Stuart Mill, the sober-minded liberal skeptic of ideology, as a model sociologist for the twentieth century, the century of ideology. In an essay of hommage to Mill that reads as a thinly veiled selfportrait, he lauds Mill as "the conscience of science whovirtually alone - sought steadfastly to keep his sociology free from ideology." True enough, for how many sociologists read Mill today, much less cite him as their vocational inspiration? Unlike Mill, many contemporary American sociologists consciously labor to connect their sociology to ideology.

\section{Feuer the Psychologist}

Although he goes largely unread by his present-day successors - to their loss-Feuer stands as one of the founders of the sociology of emotions. His work re-conceives the significance of irrationality and emotion in human affairs. Their roles were much-discussed in sociological theory in its early years, when towering European thinkers from Weber and Sorel to Pareto and Mannheim shaped its direction. During the last half-century, the dominance of cognitive social science generally and rational choice theory specifically have rendered this topic unfashionable. Feuer's interest in the dynamics of emotion inevitably led him to interweave psychology with sociology, but some sociologists have 
derided Feuer's work as excessively reliant on psychology and psychoanalysis. Indisputably, much of Feuer's work, especially Psychoanalysis and Ethics (1955) and The Conflict of Generations (1969), focuses on the psychodynamics of historical processes and social movements. Feuer's Psychoanalysis and Ethics, his first significant book, shows why psychoanalysis attracted him. In this work, he argues that, in the tradition of Mill, the primary task of the ethical philosopher should be a criticism of values, which Feuer pursued in psychoanalytic categories.

I would acknowledge that Feuer's use of Freud is at times crude or overwrought. Feuer was insufficiently critical of the thinness or sheer wrongheadedness of much Freudian theory, ignoring the plain fact that it sometimes amounts to little more than inflated speculation, grandiose assertion, and pseudo-impressive system-building - not careful scholarship, unlike Feuer's own most compelling work.

Feuer's blinkered allegiance to Freud was, of course, part of the early postwar intellectual hero-worship that Freud enjoyed, in which New York intellectuals such as Lionel Trilling, a coeval of Feuer similarly beholden to an unskeptical, exalted image of Freud, also engaged. Feuer's attraction to Freudian categories occasionally vitiates his work, when he applies it mechanically and schematically, thereby mirroring Freud's own chief weakness. Yet when he employs psychoanalysis for local illumination rather than global analysis, Feuer's studies break new ground, for they possess a psychological dimension that postwar American sociology and philosophy generally lacked. The sympathetic intellectual historian should acknowledge this fact. My own view is that Feuer occasionally surrendered his own critical intellect to the ideology of Freudian psychoanlaysis because Freudianism represented the reigning psychology available during his formative years and until the late 1960s-and because, as he astutely and courageously saw, such disciplines as American sociology, the history of ideas, and academic philosophy were themselves vitiated by the omission of any psychological perspective.

Feuer himself defended his psychologizing on two grounds. First, he held that ideology and metaphysics are anxiety-motivated dogmas that necessitate psychological, not merely social or logical, analysis. Second, Feuer's governing scholarly tenet, which invested his work with scale and significance, was that he would suppress no evidence and avoid no direction of thought that might elucidate the phenomena under study. In this respect he is notably different from disciplinary specialists who ignore evidence because it is "outside the field" or to disciplinary ideologists who deny evidence because it disrupts their dogmatic slumbers. Given such differences, I would even grant that Feuer's pioneering scholarship and refreshing heterodoxy partly owed to - and is inseparable from - a welcome (and to my mind forgivable) intellectual ambitiousness that inevitably overreached itself. For the payoff from Feuer's psychologizing outweighs the costs. His best scholarship repeatedly unveils the irrational and the emotional as sources of such phenomena as ideology, scientific creativity, political transformation, and generational rebellion. In fact, I would contend that Feuer's dogged commitment to Freudian concepts and categories in his historical research seemed to him to confirm the tenets of psychoanalysis. On this view, it is plausible that he regarded his attempt to equip sociology with a psychological dimension as part of his larger task of assuring that sociological theory was validated by empirical verification - a mission that marked him as very different from sociologically minded thinkers who drew on Freud yet largely limited themselves to theoretical work, such as Herbert Marcuse, Erich Fromn, Norman O. Brown, and numerous others among Feuer's coevals.

\section{Feuer the "Scientific Intellectual"}

Feuer's last great book is, however, completely unblemished by any mechanical application of or regrettable naïveté toward psychoanalysis. Einstein and the Generations of Science is a brilliant masterwork that advances a new theory of the origins of quantum mechanics in modern physics. Feuer's account remains sensitive throughout to the historical and cultural contexts, the social-structural arrangements, and the emotional worlds of those physicists who developed the revolutionary scientific ideas of the early twentieth century. His concepts of "isomorphemes" and "isoemotional lines" explain how and why the theory of relativity emerged when and where it did. Indeed the Einstein book represents a major contribution to the sociology of science, though here again, sociologists and historians of science fail to acknowledge that contributionunlike the case of the contributions of Feuer's generational peers in the sociology of science, such as Robert K. Merton. Indeed, given the range of Feuer's work across the physical and social sciences, he himself represents - far more so than Merton-an exemplar of the "scientific intellectual." As I have noted, his treatment of ideas across the broadest possible spectrum marks him as an evidence-based "scientific intellectual" who insists on material documentation as the ultimate arbiter of his judgments.

A memorable debate between Feuer and Merton is apposite here - and worth revisiting not only for the combination of careful historical scholarship and innovative psychobiography undergirding Feuer's characteristically heterodox conclusions, but also as a valuable moment in intellectual history. The encounter showcases two intellectual titans of twentieth-century American sociology. In 1956, in a paper presented to the Eastern Sociological Society in New York, Feuer challenged Merton's contention that the main sources of 
science owed to Protestant asceticism and piety. In typically Feuerian fashion - and with a hue of impassioned identification that forms the outline of another self-portrait- - he contended instead that early scientists possessed a profoundly hedonistic attitude that fired their creativity and desire to challenge conventional wisdom. Feuer developed this idea further in The Scientific Intellectual ([1963] 1992). Speaking of this work in his memoir, he notes: "What had begun with a study of the seventeenth-century English scientists was generalized into a sociological law that only where a hedonist-libertarian ethic prevails of the kind that leads to respect for the human body's senses and reason as an avenue to basic knowledge can a scientific movement arise.... The ethic of science was Baconian, not Calvinist.... My view of the psychological origins of science seemed to me in accord with all that psychology has learned of the impact of guilt and repression on human thinking" (1988, 40-41).

Beyond sociology proper, Feuer's life bears revealing witness to the relationship between the pursuit of truth and the transformation of the intellectual. Like many of the New York intellectuals associated with Partisan Review (such as Trilling, Irving Howe, and Dwight Macdonald), Feuer began his intellectual life as a committed Marxist dialectician and polemicist. In fact, Feuer was an exceptional case: a true Marxist intellectual. Indeed his knowledge of the life and work of Marx himself - and of the socialist tradition more generally - was sovereign in American academic and intellectual circles. Feuer edited the standard work of the basic writings of Marx and Engels in use throughout North America in the 1960s. Feuer's interdisciplinary expertise in the history of the Left, in the sociology of science, and in contemporary psychology and biography enabled him to draw rich connections between Marx's personal life and political work. It was reflected not only in Feuer's brilliant classroom lectures and several landmark published articles, but also in his novel, The Case of the Revolutionist's Daughter (1983), where Feuer uses an imagined encounter between Sherlock Holmes and Marx to explore Marx's moral failings. Feuer's knowledge of Marx later made him a formidable opponent of Soviet and Western apologists for Marxist orthodoxies.

\section{The Flight from Marx-and "Amerika"}

Unlike the "ideologists" whom he castigated, Feuer did not deny his personal or subjective experience when making his political choices. A series of events during and immediately after World War II led him step by step away from Marxist dogmas toward an ever more nuanced and flexible socialist stance. But it was a pair of traumatizing encounters in the mid-1960s that precipitated a substantial revision of his political identity and moved him beyond socialism altogether into a version of neoconservatism. The two jolting moments occurred in quick succession, triggering these turns and permanently reorienting him.

The first convulsion occurred as a visiting professor in the Soviet Union in 1963, where he found himself in direct contact with the stultifying impact of post-Stalinist orthodoxy on Soviet intellectual life. The aftereffects of these months on his subsequent development proved enduring, and they also generated many years of personal and intellectual upheaval. Indeed the last half of Feuer's life can be seen as an internal existential battle, often played out publicly in his speeches and scholarship, targeted at betrayals of the Left intelligentsias (la trahison des clercs) in general and at the false consciousness of his youth in particular, both lessons of which he readily applied to the radical excesses of American youth in the 1960s.

Feuer's late adulthood thus illustrates how the pursuit of knowledge affects political transformation. He evolved into a sophisticated analyst and a biting critic of ideology and intellectual conformity, and the USSR visit showed him how ideology as "unreason" corrupts thinking, a leitmotif of his Ideology and the Ideologists (1975). Of all his works, this book is most likely to appeal to politically minded readers. Here Feuer presents an original, incisive sociological theory of the vicissitudes of ideologies across time and space.

The second tremor that provoked Feuer's personal and political transformation, and which decisively accelerated his movement beyond socialism and the Left, occurred during the following 2 years, in 1964-65, when the Free Speech Movement occurred at Berkeley, led by student radicals affiliated with Students for a Democratic Society (SDS) and the New Left. In the late 1950s, Feuer had gained promotion to full professor of philosophy and served as chairman of the Social Science Integrated Course, an interdisciplinary Berkeley program that organized invited lectures from various university departments. Feuer himself gave the lectures in the sociological unit to audiences that averaged 1,000 students every semester. As the 1960s progressed, he found himself increasingly in conflict with Berkeley student radicals and their professorial sponsors. Drawing on a masterful grasp of the history of student movements, supplemented by a sociological perspective on his hard-won lessons regarding ideology and utopia, Feuer lectured frequently, with predictable audacity if not temerity, on the history and sociology of the irrational character of diverse student movements.

In The Conflict of Generations (1969), which Feuer considered his best book, he presented a theory of generational rebellion imprinted with his experiences at Berkeley. It is also the work that he cherished most. Strongly influenced by Freudian concepts and categories, the study met with much criticism from sociologists and New Left 
supporters who scoffed at Feuer's contention that student movements represent collective expressions of Oedipal drives. Much of their criticism is valid. Nonetheless, I regard Feuer's work on student movements as invaluable for shedding new light on the social psychology of such movements and the psychodynamics of their latent mechanisms. Elaborating on his claim that the "irrational nature" of the "generational rage" driving these movements operates by defense mechanisms such as denial and repression, Feuer told me during my 1996 visit to him that, "a strange, hysterical frame of mind [prevailed] in Berkeley during 1964-66. So if you get hold of people later, and ask them precisely what the issue was, you have a hard time getting anyone to tell you what precisely the issue was."

Feuer suffered a career "stigma" for exposing the irrational dimensions of the student movements of the 1960s and assuming a hard-line position against their excesses. Feuer was as "politically incorrect" as one could be in the 1960s. As one Berkeley student of the time phrased it to me, Feuer was "the person everyone was supposed to hate." Feuer felt persecuted, hounded, and disillusioned. He once confided to me during our Virginia talks that he was "blacklisted" so thoroughly in American (or "Amerikan") academe that he could obtain no job in any respectable philosophy or sociology department in the entire country. In a painful irony, he became aware that he would have to do what the Vietnam-era draft dodgers had done: "flee" to Canada. He secured an appointment at the University of Toronto, where he spent a fulfilling decade before returning to teach at the University of Virginia, where he concluded his active career. His completion in Toronto of both Ideology and the Ideologists and Einstein and the Generations of Science is one sign of how he flourished intellectually during his American "exile."

\section{Personal Integrity, Moral Courage, Intellectual Passion-and Their Costs}

For those unwilling to bury evidence in the dirt of ideology, Feuer's intellectual and personal trajectory warrants respect. Such intellectual (and moral) courage will never be in vogue, nor can one imagine a wave of popularity for Feuer's difficult, if rewarding, oeuvre. Yet both his political fate and intellectual achievement are highly relevant today. In sociological circles, as well as in American academe and intellectual life, Feuer was vilified and ostracized for his "heresies," often branded as a "fascist," "Nazi," "traitor," and "sellout." Contemporary anti-conformists can expect no different treatment. And so, in today's new age of the corporate university, academic celebrity, and punditocracy/ plutocracy, an era in which "public intellectuals" parade as nonstop talking heads and in which professors and administrators embrace, as they did in the 1960s, irrational pieties and orthodoxies, Feuer's writings warrant reconsideration and revaluation. This is because they possess a bracing currency.

Feuer's critical spirit of intellectual heterodoxy is also visible in his iconoclastic Imperialism and the AntiImperialist Mind (1986), which conceptualizes modern varieties of imperialism and the psychosocial sources of self-hate and guilt among Left intellectuals. Written after his turn by the late 1970s toward neoconservatism, Feuer's last major work draws a useful distinction between "progressive" and "regressive" imperialism. Characterized by the Roman, British, and French empires, which were systems of domination yet also liberated energy for the advancement of civilization, the former are often justifiable in their moderate forms and in such cases even constructive, in fact arguably part of the responsibility of great powers or empires. (Feuer gingerly defended White Man's Burden on historical grounds, disclosing the vestiges of his old allegiance to Marxist progressivism and its "laws" of History.) By contrast, examples of "regressive imperialism" include Nazi Germany and the Soviet Union, along with certain features of the Mongolian and Spanish empires that facilitated a ruthless exploitation or extermination of peoples.

Feuer's distinctions in Ideology and the Ideologists should interest students of contemporary history and political science. He condemns the politics of "moral equivalence" when making judgments of the two dominant, longregnant empires of the twentieth century: the U.S. and the USSR. The latter was far more dehumanizing and bloody, more regressive than the United States, argues Feuer, and I would agree that the supporting evidence has long been incontrovertible. Yet Feuer laments that even in the face of this evidence, many Western leftist intellectuals denied it, and a few still do. How and why can this be? Feuer asks. His analysis cogently explains how so many intelligent people on the Left could long serve as apologists for Soviet imperialism and as myopic adversaries of its only meaningful antipode: American "imperialism." Returning to his earlier work in psychobiography and the social psychology of groups, Feuer shows how Marxist intellectuals deliberately mobilized liberal guilt to safeguard their own illusions and shift attention to Western "crimes." These writings are valid, probing, and insightful. My sole regret is that he did not explicitly extend his critique of unreason as an historical force to right-wing movements, whether conservative or fascist. Like so many other dissident leftists and ex-leftists among his coevals_-including Orwell, Howe, Macdonald, and others - Feuer largely assumed that the Right was equally or more guilty of historical crimes. But because the Right bore the brunt of intellectuals' attacks, Feuer seems to have felt, like Orwell, that he hardly needed to add his critical voice to excoriate the Hitlers, Mussolinis, or even Churchills of his own day. 
Today, of course, the student rebellions of the 1960 s, as with Soviet imperialism, are no more. Yet Feuer's historically based generalizations about these social processes help us to understand how unreason and passion motor contemporary events and how a generation of new political interest groups in the academy recruit liberal guilt to support their own ideological programs-as Thomas Cushman has shown in the case of Serbian imperialism and genocide in the Balkans (and also Western leftist intellectuals' defenses of Serb atrocities). His edited collection, This Time We Knew: Western Responses to Genocide in Bosnia (1996), represents virtually a case study highlighting selected theses of Feuer. In fact, as Cushman has pointed out to me, this example of the Balkans illustrates both how Feuer's work enriches current history and how, beyond the intellectual excitement of reading Feuer's corpus, his work compels attention for its treatment of the emotional and the irrational in social life. In the beginning of the twentieth century, a Bosnian Serb student named Gavrilo Princip sparked the barbarism of World War I, a conflict that guided the direction of the rest of the century. At the fin de siecle, a Bosnian Serb psychiatrist named Radovan Karadzic initiated a genocide against European Muslims in Bosnia-Herzegovina. These two events are the symbolic markers of the beginning and the end of the twentieth century, during which reason has repeatedly capitulated before individual and collective expressions of irrationality and emotion.

Will the twenty-first century witness any abatement in the impact of unreason on human affairs? Given his discerning analysis of such phenomena in their multifarious expressions throughout history, Feuer's sociology can alert us both to their uncommon forms or disguises and to the signs of their re-emergence in our own day. Make no mistake: Feuer revered reason, but he harbored no illusions that unreason was negligible in human affairs or that the irrational could be bracketed out in social analysis. Rather, he insisted that it is only through reason that we can understand unreason and protect ourselves against it. As he wrote a year before his death in Varieties of Scientific Experience: "Rational men in our time, far from renouncing their rationalism, will in this post-Holocaust era hold all the more steadfastly to a rationalism tempered by a stoic outlook. It has in the past availed to help civilization withstand barbarian insurgence."

The genocidal terrors of recent decades should remind us: The twenty-first century requires a neo-Victorian voice in the liberal registers of Mill and Arnold.

I hereby recommend to you Lewis S. Feuer. A reappraisal - and renewed appreciation —of his work is imperative.

\section{Further Reading}

All publications listed here are by Lewis S. Feuer, unless otherwise specified.

Psychoanalysis and Ethics (C.C. Thomas, 1955).

Spinoza and the Rise of Liberalism (Boston: Beacon Press, 1958).

The Scientific Intellectual: The Psychological and Sociological Origins of Modern Science (New York: Basic Books, 1963).

The Conflict of Generations: The Character and Significance of Student Movements (New York: Basic Books, 1969).

Ideology and the Ideologists (Oxford: Blackwell, 1975).

Einstein and the Generations of Science. 2nd ed. (New Brunswick: Transaction, 1982).

The Case of the Revolutionist's Daughter: Sherlock Holmes Meets Karl Marx (Buffalo, New York: Prometheus Books, 1983).

Imperialism and the Anti-Imperialist Mind (Buffalo, New York: Prometheus Books, 1986).

Varieties of Scientific Experience: Emotive Aims in Scientific Hypotheses (New Brunswick, New Jersey: Transaction, 1995).

Sidney Hook, William O'Neill, and Roger O'Toole, Eds. Philosophy, History and Social Action: Essays in Honor of Lewis Feuer. (Dordrecht: Kluwer Academic Publishers, 1988).

Irving Louis Horowitz, The Decomposition of Sociology. (New York : Oxford University Press, 1993).

Karl Marx, Basic Writings on Politics and Philosophy. Lewis S. Feuer, ed. (New York: Anchor Books, 1959).

John Rodden, senior editor of Society, is the author of Every Intellectual's Big Brother: George Orwell's Literary Siblings and the forthcoming The Intellectual Species: Evolution or Extinction?, among other works. 